\title{
ANALISIS RETRACKING WAVEFORM DATA SATELIT ALTIMETER PADA TELUK, PERAIRAN PULAU-PULAU KECIL, DAN LAUT DALAM DI LAUT HALMAHERA
}

\author{
WAVEFORM RETRACKING ANALYSES OF ALTIMETRY SATELLITE DATA \\ AROUND GULF, SMALL ISLANDS, AND DEEP WATERS IN HALMAHERA SEA
}

\author{
Maya Eria Br Sinurat ${ }^{1 *}$, Bisman Nababan ${ }^{2}$ dan Jonson Lumban Gaol ${ }^{2}$ \\ ${ }^{1}$ Program Studi Teknologi Kelautan, Pascasarjana, FPIK-IPB, Bogor, 16680, Indonesia \\ ${ }^{2}$ Departemen Ilmu dan Teknologi Kelautan, FPIK-IPB, Bogor, 16680, Indonesia \\ *E-mail: maya_eriabrsinurat@apps.ipb.ac.id
}

\begin{abstract}
The accuracy of sea surface height (SSH) estimation from altimeter satellites is strongly influenced by waters condition and coastal land. In general, SSH estimations in offshore are accurate. However, in coastal waters, SSH estimation are inaccurate due to the reflection of signal from land. The study purpose was to retrack the waveform of Altimeter satellites in a complex the Halmahera Sea. The data used for this study were the waveform Sensor Geophysical Data Record type D (SGDR-D) of Jason-2 and Jason-3 of 2017. To retrack waveform, we used several algorithms i.e., Offset Centre of Gravity (OCOG), Iced, Threshold, and Improved Threshold. All retrackers provided significant improvement in SSH estimations except OCOG. The best retracker used in Halmahera Sea for the shallow and narrow bay was Threshold 10\%, for the deep and wide bay was Threshold 50\%, and for small islands waters were Threshold 10\% and Threshold 20\%. In general, Non-Brown waveforms were more common in the shallow and narrow bay waters (average $=63.49 \%$ ) vs. the deep and wide bay waters (average $=11.51 \%$ ) and small island waters (average $=9.57 \%)$. However, the improvement percentage of SSH estimations in the shallow and narrow bay waters was higher than the deep and wide bay waters and small islands waters. The best retrackers in the Halmahera Sea was the Threshold 10\% algorithm with the IMP value of 96.71\% on Jason-2 pass 164 .
\end{abstract}

Keywords: altimetry, Jason-2, Jason-3, retracking, waveform

\begin{abstract}
ABSTRAK
Akurasi estimasi tinggi muka laut (SSH) dari satelit altimeter sangat dipengaruhi oleh kondisi perairan dan daratan disekitar perairan tersebut. Estimasi SSH di laut lepas umumnya sudah akurat. Namun, pada daerah pantai, estimasi SSH kurang akurat karena gangguan pantulan sinyal dari daratan. Penelitian ini bertujuan untuk melakukan analisis retracking waveform satelit altimeter pada perairan yang kompleks di Laut Halmahera. Data yang digunakan pada penelitian ini yaitu data waveform dari Sensor Geophysical Data Record type D (SGDR-D) Jason-2 dan Jason-3 tahun 2017. Algoritma retracking yang digunakan yaitu Offset Centre of Gravity (OCOG), Iced, Threshold, dan Improved Threshold. Hasil retracking waveform menunjukkan semua retracker memberikan perbaikan data SSH yang signifikan kecuali OCOG. Retracker yang paling cocok diaplikasikan di Laut Halmahera pada teluk dangkal dan sempit yaitu Threshold 10\%, pada teluk dalam dan lebar yaitu Threshold 50\%, serta pada perairan dekat pulau pulau kecil yaitu Threshold 10\% dan Threshold 20\%. Secara umum, NonBrown waveform lebih banyak ditemukan di perairan teluk dangkal dan sempit (rata-rata $=63,49 \%$ ) dibandingkan dengan teluk dalam dan lebar (rata-rata=11,51\%) dan perairan pulau-pulau kecil (ratarata $=9,57 \%$ ). Namun demikian, tingkat perbaikan data SSH di perairan teluk dangkal dan sempit lebih tinggi dibandingkan dengan teluk dalam dan lebar serta perairan pulau-pulau kecil dan laut dalam. Persentase peningkatan perbaikan data (IMP) tertinggi yaitu 96,71\% dengan algoritma Improved Threshold 10\% pada Jason-2 pass 164.
\end{abstract}

Kata kunci: altimeter, Jason-2, Jason-3, retracking, waveform 


\section{PENDAHULUAN}

Satelit altimeter memiliki peran penting dalam pengetahuan di bidang kelautan. Satelit altimeter memiliki level akurasi hingga tingkat $\mathrm{cm}$, memiliki area cakupan luas dan tingkat pengulangan yang tinggi (Guo et al., 2010). Data altimeter digunakan untuk pemantauan variasi tinggi muka laut (sea surface height). Sea surface height (SSH) yang diamati memiliki peranan penting untuk beberapa aplikasi seperti kajian oseanografi (Chelton et al., 2001), pemodelan pasang surut (Savcenko and Bosch, 2008), tren dan variabilitas SSH (Saraceno et al., 2014). Data altimeter pantai berpotensi digunakan untuk mengkaji dinamika pantai dan variabilitas paras laut di perairan pesisir Indonesia (Lumban-Gaol et al., 2018).

Estimasi SSH dari satelit altimeter dipengaruhi oleh bentuk waveform. Waveform data satelit altimeter umumnya memiliki tiga bagian utama yaitu thermal noise, leading edge, dan trailing edge. Thermal noise merupakan bagian dari waveform yang menunjukkan waktu pada saat sinyal belum menyentuh permukaan laut sehingga belum terjadi peningkatan power. Leading edge merupakan bagian waveform pada saat pertama kali menyentuh permukaan laut (titik nadir) sehingga terjadi peningkatan power sampai titik power tertinggi sedangkan trailing edge merupakan pantulan energi gelombang di sekeliling titik nadir (Deng and Featherstone, 2006; Gommenginger et al., 2011). Estimasi SSH diperoleh dari pengukuran range pada titik tengah leading edge (Bao et al., 2008).

Waveform di laut lepas umumnya memiliki bentuk ideal yang pertama kali ditemukan oleh Brown (1997) (Gambar 1a). Titik tengah leading edge Brown waveform berada pada gate yang sudah ditetapkan oleh satelit. Adapun waveform yang terbentuk pada perairan pantai dan perairan dangkal merupakan waveform kompleks (Non-Brown waveform) karena dikontaminasi oleh topografi pantai dan proses geofisika. Keadaan tersebut menyebabkan posisi leading edge pada Non-Brown waveform (Gambar 1b) menjadi tidak sesuai dengan bentuk normal seperti terlihat pada model Brown waveform sehingga menghasilkan estimasi SSH yang kurang akurat (Yang et al., 2008; Bao et al., 2008).
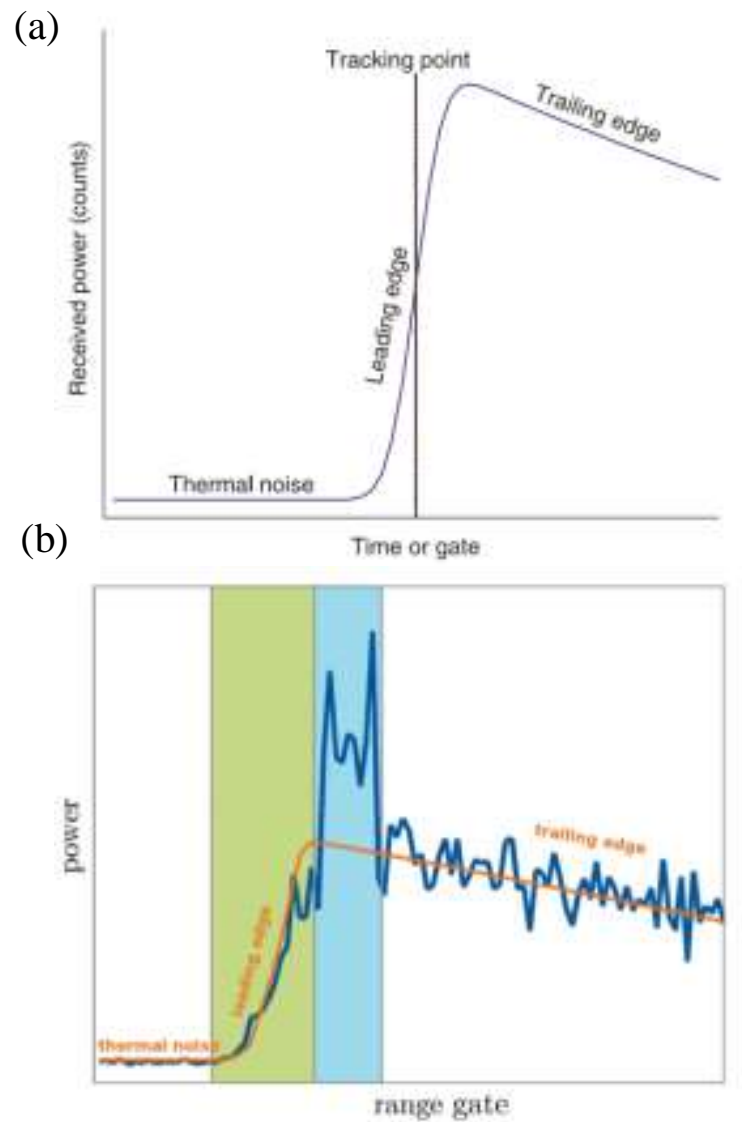

Gambar 1. Contoh ideal waveform (a) Brown-waveform yang ditemui pada laut lepas (Deng and Featherstone 2006); Waveform yang terganggu daratan (warna biru) (Roscher et al. 2017).

Salah satu cara untuk meningkatkan akurasi data SSH di daerah pantai yaitu dengan retracking waveform (Deng and Featherstone 2006; Hwang et al., 2006; Bao et al., 2008; Lee et al., 2010; Guo et al., 2010). Retracking waveform merupakan suatu algoritma perhitungan ulang data 
altimeter untuk mengoreksi jarak satelit dengan permukaan air berdasarkan waveform dari power sinyal saat pertama kali menyentuh permukaan air (titik nadir) (Bao et al., 2008). Sandwell and Smith (2005) berhasil meningkatkan akurasi data altimeter ERS-1 di daerah pantai dengan retracking waveform hingga 36\%. Hwang et al. (2006) melakukan retracking waveform data altimeter Geosat di perairan Taiwan dengan persentasi peningkatan akurasi tertinggi yaitu 20\%. Bao et al. (2008) juga berhasil melakukan retracking waveform data altimeter ERS-1 di Laut Cina dengan persentase peningkatan hingga $77,9 \%$. Pada tahun 2010, Guo et al. melakukan retracking waveform data EnviSat di perairan pantai Mediterrania dengan persentase peningkatan hingga 59,8\%. Idris and Deng (2012) berhasil meningkatkan akurasi data Jason-1 dan Jason-2 di Australia sekitar Great Barrier Reef hingga $86,96 \%$ dengan retracking waveform. Passaro et al. (2014) juga telah mengembangkan metode baru retracking waveform yaitu The Adaptive Leading Edge Subwaveform (ALES) dan diaplikasikan ke data Envisat, Jason-1dan Jason-2 di Teluk Trieste dan Teluk Mossel, pantai Afrika Selatan. Idris et al. (2017) mengembangkan metode Coastal Altimetry Waveform Retracking Expert System (CAWRES) yang mampu meningkatkan akurasi lebih tinggi dibandingkan dengan metode sebelumnya. Roscher et al. (2017) juga mengembangkan metode SpasioTemporal Altimetry Retracking (STAR) yang diaplikasikan ke data Jason-2 perekaman di Trieste dan Bangladesh dan mampu memberikan perbaikan akurasi yang lebih baik dari metode ALES dan metode sebelumnya.

Retracking waveform pada daerah pesisir Indonesia masih sangat minim dilakukan sedangkan data SSH perairan Indonesia yang akurat sangat dibutuhkan untuk pemantauan SSH serta dampaknya terhadap pulau-pulau kecil di perairan Indonesia. Retracking waveform data altimeter yang telah dilakukan di Indonesia yaitu retracking di pesisir selatan Jawa Tengah dan Jawa Barat (Adrian, 2013), retracking waveform Jason-2 di perairan Jawa Timur (Sumerta, 2013), retracking waveform Jason-2 di pesisir Pulau Mentawai, Sumatera Barat (Pamungkas, 2014), serta retracking waveform di perairan pulau Jawa (Hakim et al., 2015 dan Nababan et al., 2018). Hasil penelitian Nababan et al. (2018) menunjukkan bahwa garis pantai yang semakin kompleks menghasilkan Non-Brown waveform yang semakin banyak dibandingkan dengan garis pantai kurang kompleks pada perairan dangkal Laut Jawa. Non-Brown waveform akan menghasilkan nilai estimasi SSH yang kurang akurat dengan menggunakan algoritma standard Oceanic.

Penelitian retracking waveform di Indonesia hanya terbatas pada perairan di Pulau Jawa dan Sumatera Barat sehingga retracking waveform perlu dilakukan di perairan Indonesia lainnya seperti Laut Halmahera. Laut Halmahera merupakan perairan yang kompleks memiliki kedalaman yang bervariasi dari laut dangkal sampai laut dalam, memiliki banyak teluk dengan keragaman kedalaman yang bervariasi, dilalui oleh arus lintas Indonesia (Arlindo), dan berhubungan langsung dengan Samudera Pasifik. Hal itu menyebabkan Laut Halmahera memiliki kondisi oseanografi yang kompleks. Laut Halmahera juga memiliki pulau-pulau kecil yang rentan akan kenaikan muka laut (sea level rise) sehingga SSH di perairan tersebut perlu dipantau. Pemantauan dan kajian SSH tersebut memerlukan data yang akurat terutama di daerah pantai sehingga penelitian mengenai retracking waveform data satelit altimeter di daerah ini perlu dilakukan. Retracking waveform pada penelitian ini dilakukan pada data satelit Jason-2 dan Jason 3 yang melewati Laut Halmahera seperti daerah teluk dan perairan yang berada di dekat pulau-pulau kecil. Tujuan penelitian ini adalah melakukan retracking waveform dan 
menganalisis hasil retracking waveform satelit altimeter Jason-2 dan Jason-3 yang melewati teluk dangkal, teluk dalam, perairan dekat pulau-pulau kecil, dan laut dalam di Laut Halmahera.

\section{METODE PENELITIAN}

\subsection{Lokasi dan Data Penelitian}

Lokasi pengamatan mencakup Laut Halmahera mulai dari $127^{\circ} 24^{\prime} 59,38^{\prime \prime}$ BT hingga $130^{\circ} 24^{\prime} 40,22^{\prime \prime}$ BT dan $2^{\circ} 29^{\prime} 35,84^{\prime \prime}$
LU hingga 1 1 57'24,89" LS (Gambar 2). Data yang digunakan pada penelitian ini terdiri dari data lintasan satelit altimeter, data satelit altimeter Jason-2 (pass 75 dan 164) dan Jason-3 (pass 253 dan 164) level 2 yaitu SGDR (Sensor Geophysical Data Record) tipe D yang melintasi Laut Halmahera pada Januari 2017 (Tabel 1), data Earth Gravitational Model 2008 (EGM08) dan data Batimetri Nasional (BATNAS) yang dipublikasi oleh Badan Informasi Geospasial (BIG).

Tabel 1. Koordinat pengamatan waveform di Laut Halmahera.

\begin{tabular}{lccccc}
\hline \multirow{2}{*}{ Satelit } & \multirow{2}{*}{ Pass } & \multicolumn{2}{c}{ Koordinat Awal } & \multicolumn{2}{c}{ Koordinat Akhir } \\
\cline { 3 - 5 } & & Lintang & Bujur & Lintang & Bujur \\
\hline \multirow{2}{*}{ Jason-2 } & 164 & $1^{\circ} 57^{\prime} 39,02^{\prime \prime} \mathrm{LS}$ & $128^{\circ} 58^{\prime} 27,28^{\prime \prime} \mathrm{BT}$ & $2^{\circ} 24^{\prime} 15,00^{\prime \prime} \mathrm{LU}$ & $127^{\circ} 24^{\prime} 55,78^{\prime \prime} \mathrm{BT}$ \\
& 75 & $1^{\circ} 57^{\prime} 14,61^{\prime \prime L S}$ & $128^{\circ} 59^{\prime} 26,48^{\prime \prime} \mathrm{BT}$ & $2^{\circ} 02^{\prime} 58,36 " \mathrm{LU}$ & $130^{\circ} 24^{\prime} 55,09^{\prime \prime} \mathrm{BT}$ \\
\multirow{2}{*}{ Jason-3 } & 164 & $1^{\circ} 57^{\prime} 32,96 " \mathrm{LS}$ & $130^{\circ} 23^{\prime} 10,03^{\prime \prime} \mathrm{BT}$ & $2^{\circ} 29^{\prime} 48,66 " \mathrm{LU}$ & $128^{\circ} 47^{\prime} 38,41^{\prime \prime} \mathrm{BT}$ \\
& 253 & $1^{\circ} 57^{\prime} 42,45^{\prime \prime} \mathrm{LS}$ & $1^{\circ} 7^{\circ} 33^{\prime} 55,41^{\prime \prime} \mathrm{BT}$ & $2^{\circ} 29^{\prime} 47,76^{\prime \prime} \mathrm{LU}$ & $129^{\circ} 09^{\prime} 15,93^{\prime \prime} \mathrm{BT}$ \\
\hline
\end{tabular}
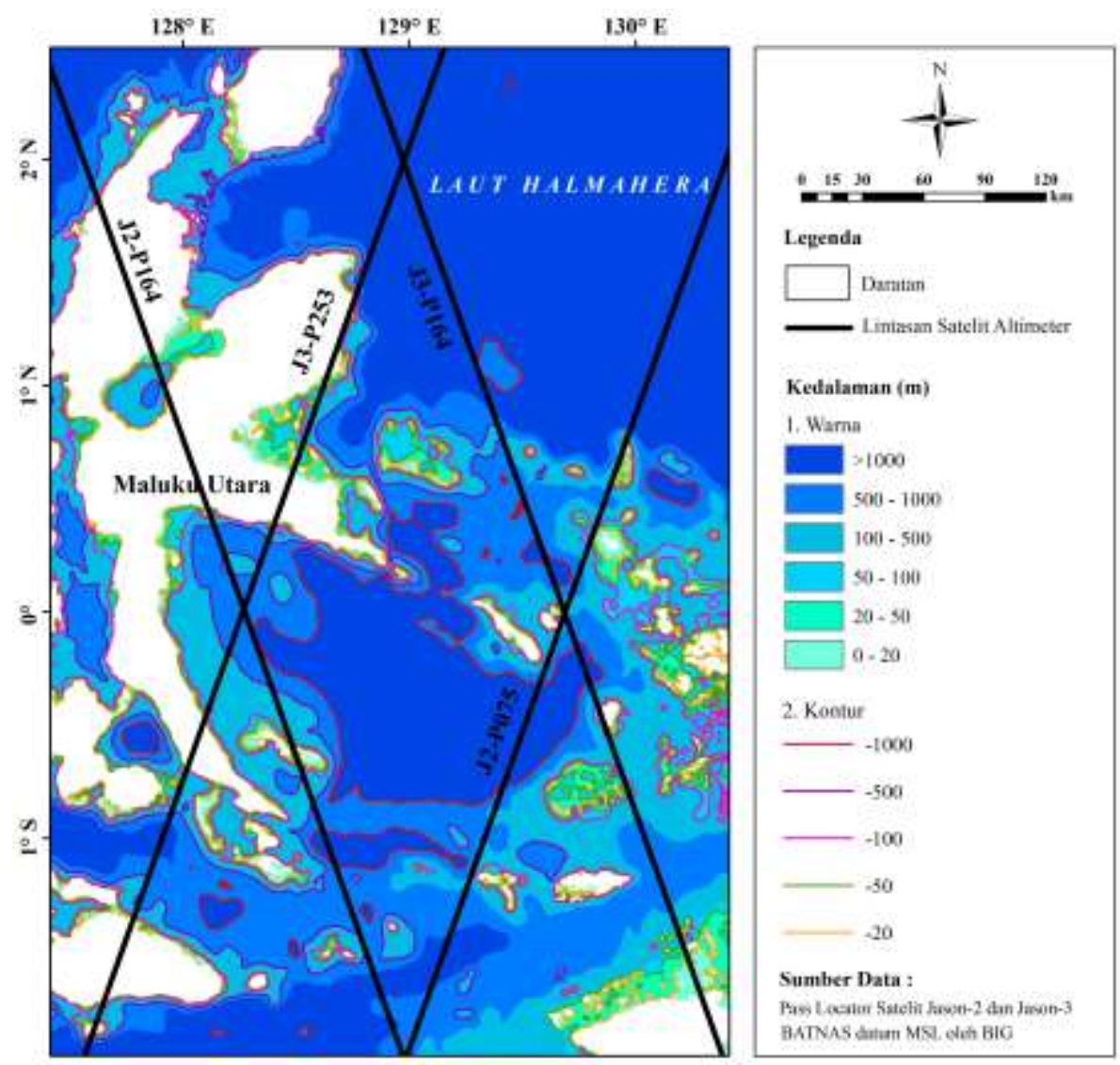

Gambar 2. Lokasi Penelitian. Garis warna hitam menandakan track dari Satelit Altimeter Jason-2 (J2) dan Jason-3 (J3). 


\subsection{Retracking waveform}

Retracking waveform pada penelitian ini dilakukan pada setiap lintasan yang melewati perairan Halmahera dengan koordinat yang terdapat pada Tabel 1 . Retracking waveform dilakukan dengan beberapa algoritma (retracker) yaitu Ocean (on-board retracker yang sudah ada di dalam data SGDR-D), Ice (Martin et al., 1983), Offset Centre of Gravity (OCOG) (Wingham et al., 1986), Threshold (Davis, 1995 dan 1997), Improved Threshold (Hwang et al., 2006). Algortima Threshold dan Improved Threshold diaplikasikan dengan beberapa ambang batas yaitu 10\%, 20\%, dan 50\%). Retracking dengan beberapa algoritma tersebut menghasilkan gate yang memotong posisi tengah leading edge sehingga dapat dilakukan koreksi jarak antara satelit dengan permukaan bumi dengan persamaan berikut (Anzenhofer et al., 1999; Guo et al., 2010 dan Yang et al., 2012):

$d_{r}=\frac{e \times \Delta G_{a}}{2} \times\left(G_{r}-G_{0}\right)$

$R_{r}=R+d_{r}$

$d_{r}$ merupakan koreksi ketinggian satelit dengan permukaan hasil retracking (m), c merupakan kecepatan cahaya (299792458 $\mathrm{m} / \mathrm{s}), \Delta G_{a}$ merupakan interval waktu untuk satu gerbang pengamatan, $G_{r}$ merupakan nomor gerbang leading edge point hasil retracking, $G_{0}$ merupakan nilai gerbang yang ditentukan pada satelit, $R$ merupakan jarak hasil pengukuran satelit (m), dan $R_{r}$ merupakan jarak hasil retracking $(\mathrm{m})$.

Jarak hasil retracking $\left(R_{r}\right)$ dikoreksi untuk memperoleh jarak terkoreksi $\left(R_{\text {corr }}\right)$. Chelton et al. (2001) menyatakan bahwa komponen koreksi nilai range terdiri dari koreksi atmosferik, sea state bias, dan koreksi pasang surut. Pada penelitian ini, koreksi yang dilakukan terdiri dari koreksi ionosfer $\left(\Delta h_{\text {iono }}\right)$, koreksi troposfer basah $\left(\Delta h_{w e t}\right)$, koreksi troposfer kering $\left(\Delta h_{d r y}\right)$, koreksi bias kondisi laut $\left(\Delta h_{s s b}\right)$, koreksi pasang surut $\left(h_{\text {tides }}\right)$, dan koreksi atmosferik dinamis $\left(h_{a t m}\right)$. Perhitungan untuk menghasilkan jarak terkoreksi dapat dilihat pada persamaan berikut (Andersen and Scharroo, 2011):

$$
\begin{aligned}
& R_{c o r r}=R_{r}-\Delta h_{d x y}-\Delta h_{\text {wet }}-\Delta h_{\text {iono }}- \\
& \Delta h_{s c b}-h_{\text {tides }}-h_{a t m}
\end{aligned}
$$

Nilai SSH hasil retracking dilakukan dengan menggunakan persamaan berikut (Yang et al., 2008):

$S S H=H-R_{c}$

\subsection{Visualisasi dan Perhitungan Kemampuan Hasil Retracking Waveform}

SSH hasil retracking dari beberapa metode divisualisasi bersamaan dengan SSH onboard (Ocean retracker), alt echo type dan geoid (EGM08). Alt echo type akan aktif ('on') pada SSH yang memiliki pola NonBrown sehingga dapat dilihat ke-mampuan setiap retracker dalam mem-perbaiki data SSH yang kurang akurat berdasarkan pola geoid. SSH hasil retracker yang memiliki pola menyerupai geoid merupakan $\mathrm{SSH}$ yang lebih baik sehingga retracker tersebut memberikan hasil perhitungan yang lebih tepat.

Kemampuan hasil retracking dapat diketahui dengan menghitung peningkatan persentase atau Improvement Percentage (IMP) sehingga dapat ditentukan retracker terbaik yang memiliki persentase peningkatan akurasi paling tinggi. IMP dari beberapa metode retracking dihitung dengan mencari nilai simpangan baku atau standard deviation (STD) dari selisih antara SSH dengan geoid (Hwang et al., 2006) menggunakan persamaan berikut:

$\sigma_{\text {Ocean atau Rebraching }}=\left(\frac{1}{\mathrm{~N}} \sum_{i=1}^{\mathrm{N}}\left(x_{i}-\bar{x}\right)^{2}\right)^{\frac{1}{2}}$ 
$I M P=\frac{\sigma_{\text {Ocsan }} \sigma_{\text {Retracking }}}{\sigma_{\text {Ocean }}} \times 100 \%$

$\sigma_{\text {ocean }}$ merupakan SD dari selisih antara SSH hasil perhitungan metode ocean retracking dengan geoid (EGM08) dan $\sigma_{\text {Retracking }}$ merupakan SD dari selisih antara SSH hasil retracking dengan geoid. Selain IMP, kemampuan retracking waveform juga ditunjukkan oleh success rate (SR). SR merupakan persentase jumlah waveform yang dapat dihitung ulang (retracking) oleh suatu algoritma dari jumlah total waveform.

\section{HASIL DAN PEMBAHASAN}

Hasil retracking waveform menunjukkan bahwa setiap retracker menghasilkan performa yang berbeda-beda terhadap perbaikan data pada setiap lintasan Jason-2 dan Jason-3 yang melewati Laut Halmahera. Hal itu ditunjukkan oleh perbedaan hasil estimasi SSH dan IMP dari setiap retracker. Guo et al. (2010) dan Yang et al. (2008) mengungkapkan bahwa adanya perbedaan hasil retracking waveform dikarenakan setiap retracker memiliki kelebihan dan kekurangan berdasarkan kondisi perairan. Hasil retracking waveform di daerah teluk berbeda dengan di perairan dekat pulau-pulau kecil dan laut dalam.

\subsection{Retracking Waveform di Perairan Teluk}

Hasil retracking waveform satelit Jason-2 dan Jason-3 perairan teluk di Laut Halmahera menunjukkan adanya perbaikan estimasi nilai SSH yang signifikan. Gambar 3 dan Gambar 4 menunjukkan bahwa retracking waveform memberikan perbaikan data SSH ditunjukkan dengan pola SSH hasil retracking yang lebih mengikuti pola geoid dibandingkan dengan SSH hasil perhitungan onboard (ocean). Retracking waveform juga memberikan estimasi SSH pada kekosongan data yang tidak dapat diestimasi oleh ocean retracker (garis berwarna hijau). SSH hasil retracking waveform menggunakan algoritma Threshold 10\% di Teluk Kao (Gambar 3a) menunjukkan pola yang mengikuti pola geoid meskipun nilainya lebih tinggi dibandingkan nilai estimasi ocean (over estimated).

Retracking waveform menggunakan Improved Threshold 10\% di Teluk Buli (Gambar 4a) juga memperbaiki SSH dan mengestimasi SSH pada beberapa data ocean yang kosong dan memiliki pola SSH yang mirip dengan geoid meskipun pada 1,041 LU hingga 1,054 LU, estimasi yang dihasilkan sangat tinggi. Hasil retracking waveform menggunakan algoritma Threshold 50\% di Teluk Weda (Gambar 3b dan Gambar 4a) memiliki pola SSH yang mirip dengan geoid dan nilai SSH yang tidak over estimated dari algoritma ocean. Adapun SSH hasil retracking waveform menggunakan algoritma OCOG di Teluk Kao, Teluk Buli dan Teluk Weda memiliki pola yang sangat tidak beraturan dan tidak mengikuti pola geoid terutama di daerah alt echo type 'on'.

Estimasi SSH oleh ocean retracker umumnya akurat hanya sampai $10 \mathrm{~km}$ dari daratan tergantung kondisi geografi (Wang et al. 2017). Namun, retracking waveform pada daerah teluk di Laut Halmahera mampu menghasilkan data yang akurat lebih dekat lagi ke arah daratan. Hasil retracking pada Teluk Weda memperbaiki estimasi SSH hingga $0,023^{\circ}$ atau sekitar $2,6 \mathrm{~km}$ dari daratan. Hal ini sesuai dengan hasil retracking waveform di sekitar perairan teluk Pulau Tsushima, Jepang oleh Wang et al. (2017) yang mampu menghasilkan estimasi data SSH yang akurat hingga $3 \mathrm{~km}$ dari daratan. 

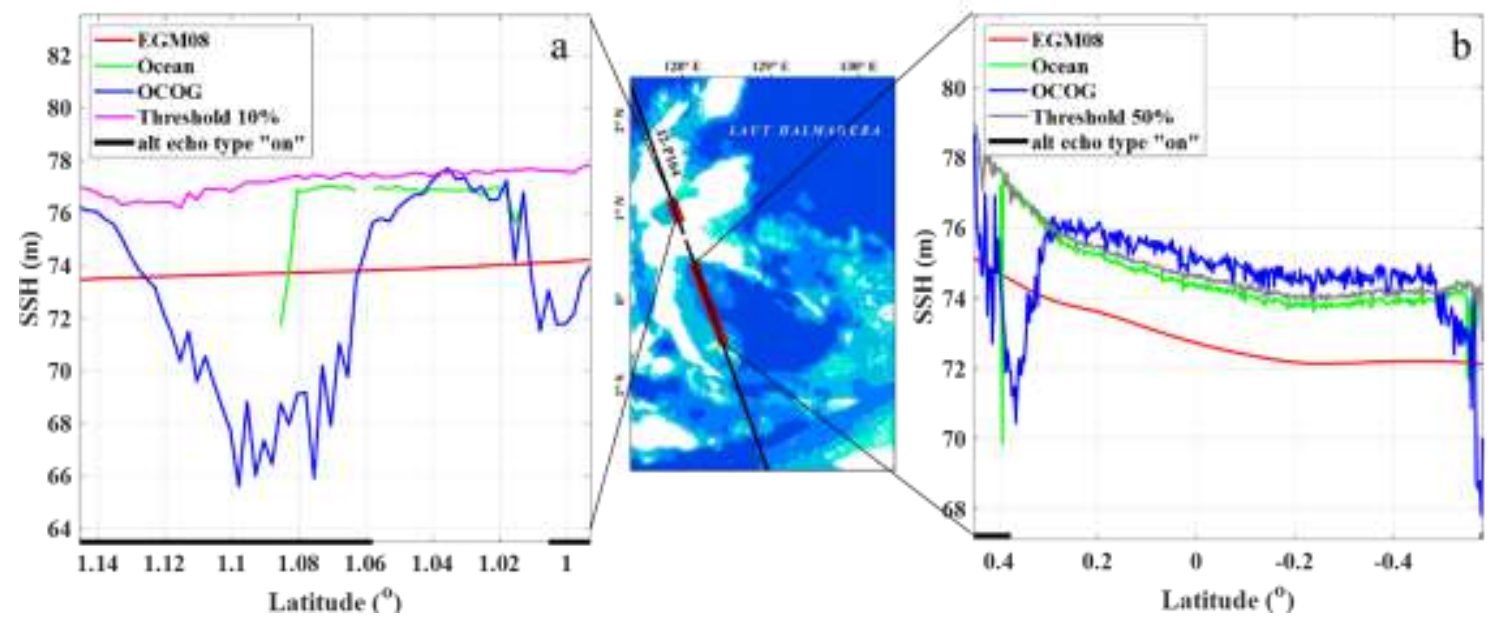

Gambar 3. SSH hasil retracking waveform satelit Jason-2 pass 164 di daerah Teluk. (a) Teluk Kao, (b) Teluk Weda.
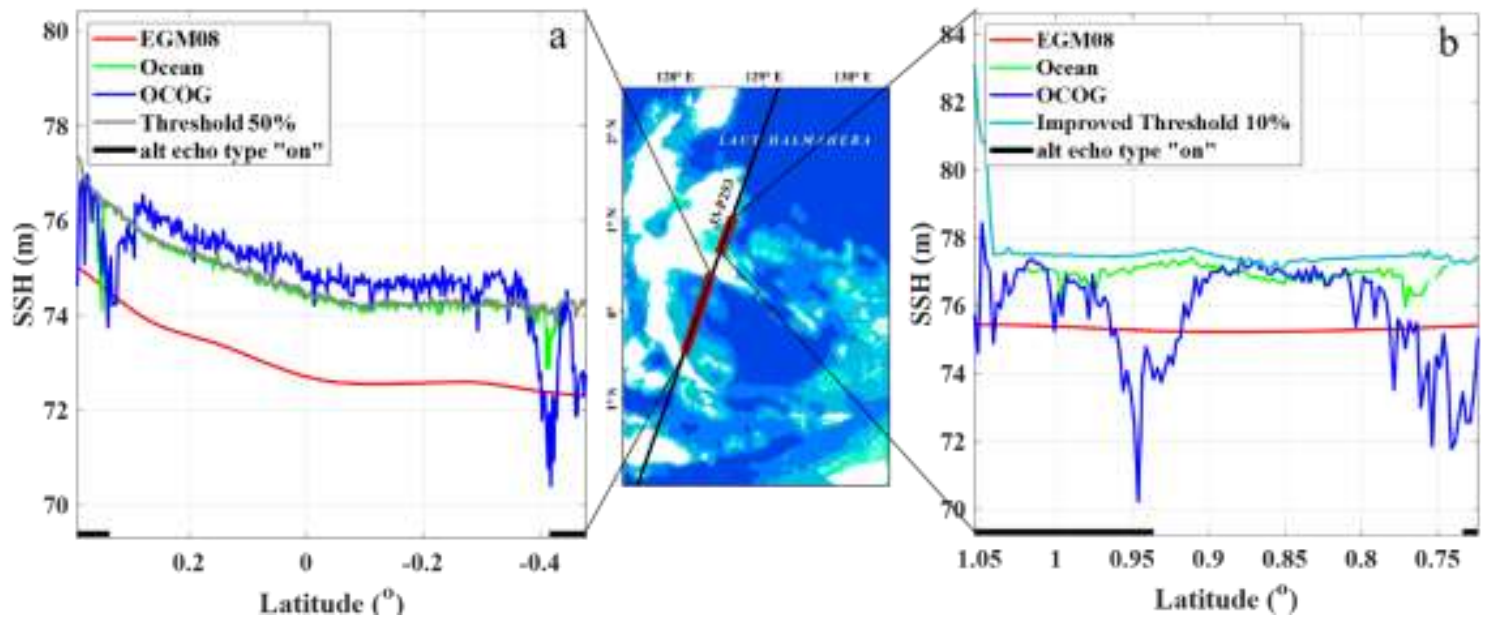

Gambar 4. SSH hasil retracking waveform satelit Jason-3 pass 253 di daerah Teluk. (a) Teluk Weda, (b) Teluk Buli.

Tabel 2. Performa hasil retracking waveform Jason-2 pass 164 dan Jason-3 pass 253 dengan beberapa algoritma (retracker) di daerah teluk.

\begin{tabular}{|c|c|c|c|c|c|}
\hline \multirow{2}{*}{ Satelit } & \multirow{2}{*}{ Pass } & \multirow{2}{*}{ Region } & \multirow{2}{*}{ Retracker } & \multicolumn{2}{|c|}{ Peforma } \\
\hline & & & & $\operatorname{IMP}(\%)$ & SR (\%) \\
\hline \multirow{9}{*}{ Jason-2 } & \multirow{9}{*}{164} & \multirow{9}{*}{ Teluk Kao } & OCOG & $-10,75$ & 100 \\
\hline & & & Threshold $10 \%$ & 96,23 & 100 \\
\hline & & & Threshold 20\% & 93,73 & 100 \\
\hline & & & Threshold 50\% & 64,72 & 100 \\
\hline & & & Improved Threshold $10 \%$ & 96,71 & 100 \\
\hline & & & Improved Threshold $20 \%$ & 94,86 & 100 \\
\hline & & & Improved Threshold $50 \%$ & 64,72 & 100 \\
\hline & & & Ice & 83,78 & 100 \\
\hline & & & Ocean & 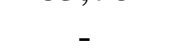 & 48,4 \\
\hline
\end{tabular}




\begin{tabular}{|c|c|c|c|c|c|}
\hline \multirow{11}{*}{ Satelit } & \multirow{11}{*}{ Pass } & \multirow{2}{*}{ Region } & \multirow{2}{*}{ Retracker } & \multicolumn{2}{|c|}{ Peforma } \\
\hline & & & & $\operatorname{IMP}(\%)$ & SR $(\%)$ \\
\hline & & \multirow{9}{*}{ Teluk Weda } & OCOG & $-192,16$ & 100 \\
\hline & & & Threshold 10\% & 47,61 & 100 \\
\hline & & & Threshold 20\% & 46,86 & 100 \\
\hline & & & Threshold 50\% & 49,05 & 100 \\
\hline & & & Improved Threshold $10 \%$ & 46,25 & 100 \\
\hline & & & Improved Threshold $20 \%$ & 42,92 & 100 \\
\hline & & & Improved Threshold 50\% & 40,22 & 100 \\
\hline & & & Ice & 46,25 & 100 \\
\hline & & & Ocean & - & 95,41 \\
\hline \multirow{18}{*}{ Jason-3 } & \multirow{18}{*}{253} & \multirow{9}{*}{ Teluk Buli } & OCOG & $-488,9$ & 100 \\
\hline & & & Threshold 10\% & 56,11 & 100 \\
\hline & & & Threshold 20\% & 45,58 & 100 \\
\hline & & & Threshold 50\% & 32,26 & 100 \\
\hline & & & Improved Threshold $10 \%$ & 50.83 & 100 \\
\hline & & & Improved Threshold $20 \%$ & 37,03 & 100 \\
\hline & & & Improved Threshold $50 \%$ & 19,88 & 100 \\
\hline & & & Ice & 42,35 & 100 \\
\hline & & & Ocean & - & 82,71 \\
\hline & & & OCOG & $-200,57$ & 100 \\
\hline & & & Threshold 10\% & 52,91 & 100 \\
\hline & & & Threshold 20\% & 56,12 & 100 \\
\hline & & & Threshold 50\% & 60,97 & 100 \\
\hline & & Teluk Weda & Improved Threshold $10 \%$ & 51,84 & 100 \\
\hline & & & Improved Threshold $20 \%$ & 57,59 & 100 \\
\hline & & & Improved Threshold $50 \%$ & 57,55 & 100 \\
\hline & & & Ice & 59,98 & 100 \\
\hline & & & Ocean & - & 91,4 \\
\hline
\end{tabular}

Hasil perhitungan IMP di perairan teluk Laut Halmahera (Tabel 2) menunjukkan bahwa setiap retracker memberikan performa perbaikan data $\mathrm{SSH}$ yang berbeda-beda. Hampir semua retracker mampu meningkatkan akurasi data $\mathrm{SSH}$ di Teluk Kao dengan IMP diatas $80 \%$ dengan retracker terbaik yaitu Threshold $10 \%$ dan Improved Threshold 10\%. Kedua retracker ini mampu memperbaiki data SSH di Teluk Kao dengan perbedaan persentase hanya $0,49 \%$ sehingga performa kedua retracker ini tidak memiliki perbedaan yang signifikan. Threshold $10 \%$ juga merupakan retracker terbaik di Teluk Buli meskipun persentase peningkatannya dibawah 60\%. Hasil retracking di Teluk Buli memperlihatkan perbedaan performa yang signifikan pada setiap retracker ditandai dengan nilai IMP yang sangat beragam dibandingkan dua teluk lainnya. Sebaliknya, hasil retracking di Teluk Weda memperlihatkan IMP yang hampir sama pada setiap retracker meskipun Threshold 50\% memberikan perbaikan terbaik di Teluk Weda baik pada Jason-3 pada Jason-2 pass 164 maupun Jason-3 pass 253. Retracker-retracker terbaik tersebut memiliki kemiripan dengan hasil retracking yang dilakukan oleh Nababan et al. (2018) di selatan Jawa dan Laut Jawa.

Persentase perbaikan tertinggi di daerah teluk Laut Halmahera terdapat pada Teluk Kao (Jason-2 pass 164) yaitu 96,71\% mengunakan algoritma Improved Threshold 
10\%. Pada Teluk Kao terdapat banyak data yang tidak mengikuti pola Brown sehingga banyak data yang tidak dapat diestimasi oleh ocean. Persentase SR pada Tabel 3 memperlihatkan bahwa algoritma ocean hanya mampu mengestimasi $48,4 \%$ dari total data waveform di Teluk Kao. Adapun persentase perbaikan terendah diperoleh dari estimasi menggunakan OCOG. OCOG tidak menghasilkan perbaikan data dan bahkan memberikan penurunan akurasi (IMP bernilai negatif). Hal tersebut dikarenakan algoritma OCOG melakukan retracking hanya dengan pendekatan statistik berdasakan perhitungan antara lebar gate dengan lebar amplitudonya (Guo et al., 2010).

Hasil analisis retracking waveform di perairan teluk menunjukan perbedaan perbaikan data antara teluk yang lebih dangkal (kedalaman kurang dari $500 \mathrm{~m}$ ) dan teluk dalam (kedalaman lebih dari $500 \mathrm{~m}$ ). Performa retracking waveform pada teluk yang lebih dangkal dan sempit (Teluk Kao) lebih baik dibandingkan pada teluk yang lebih dalam dan lebar (Teluk Weda). Hal ini disebabkan persentase Non-Brown wave-form di teluk dangkal dan sempit lebih tinggi dibandingkan teluk dalam dan lebar serta perairan dekat pulau-pulau kecil. Persentase rata-rata Non-Brown waveform di teluk dangkal dan sempit adalah $63,49 \%$ sedangkan di teluk dalam dan lebar adalah 11,51\%. Selain itu, rata-rata IMP yang dihasilkan pada teluk dangkal dan sempit juga lebih tinggi mencapai 84,96\% meskipun pada teluk dangkal yang terdapat banyak pulau-pulau kecil (Teluk Buli) memiliki hasil yang hampir sama dengan teluk dalam. IMP rata-rata pada teluk dangkal, sempit, dan terdapat banyak pulau-pulau kecil yaitu 40,58\% dan IMP ratarata pada teluk dalam dan lebar yaitu 51,03\%. Adapun retracker yang paling sesuai pada teluk yang lebih dangkal dan sempit yaitu Threshold 10\% sedangkan retracker yang cocok diaplikasikan pada teluk dalam dan lebar yaitu Threshold 50\%.

\subsection{Retracking Waveform di Perairan Pulau-Pulau Kecil dan Laut Dalam}

Hasil retracking waveform pada satelit Jason-3 pass 164 dan Jason-2 pass 75 yang melewati pulau-pulau kecil dan laut dalam memberikan perbaikan terhadap data SSH. Gambar 5 dan Gambar 6 menunjukkan bahwa retracking waveform menghasilkan pola $\mathrm{SSH}$ yang menyerupai geoid kecuali OCOG. Untuk melihat SSH hasil retracking lebih jelas, dilakukan deliniasi pada lintasan Jason2 pass 75 yang terdapat alt echo type "on" yaitu pada 0,03018 LS hingga 0,3729 LS yang terletak diantara dua pulau kecil (Gambar 6b).
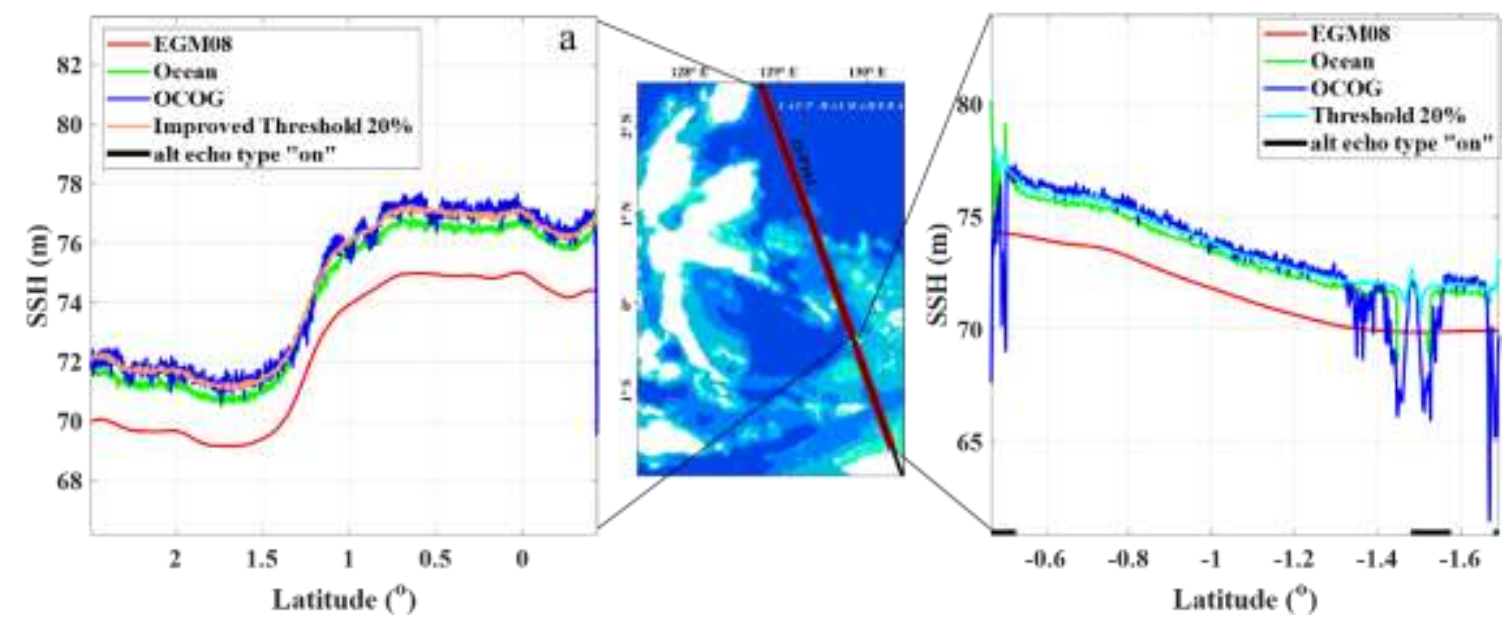

Gambar 5. SSH hasil retracking waveform satelit Jason-3 pass 164 di Laut Halmahera. (a) Bagian atas Pulau Gag, (b) Bagian bawah Pulau Gag. 


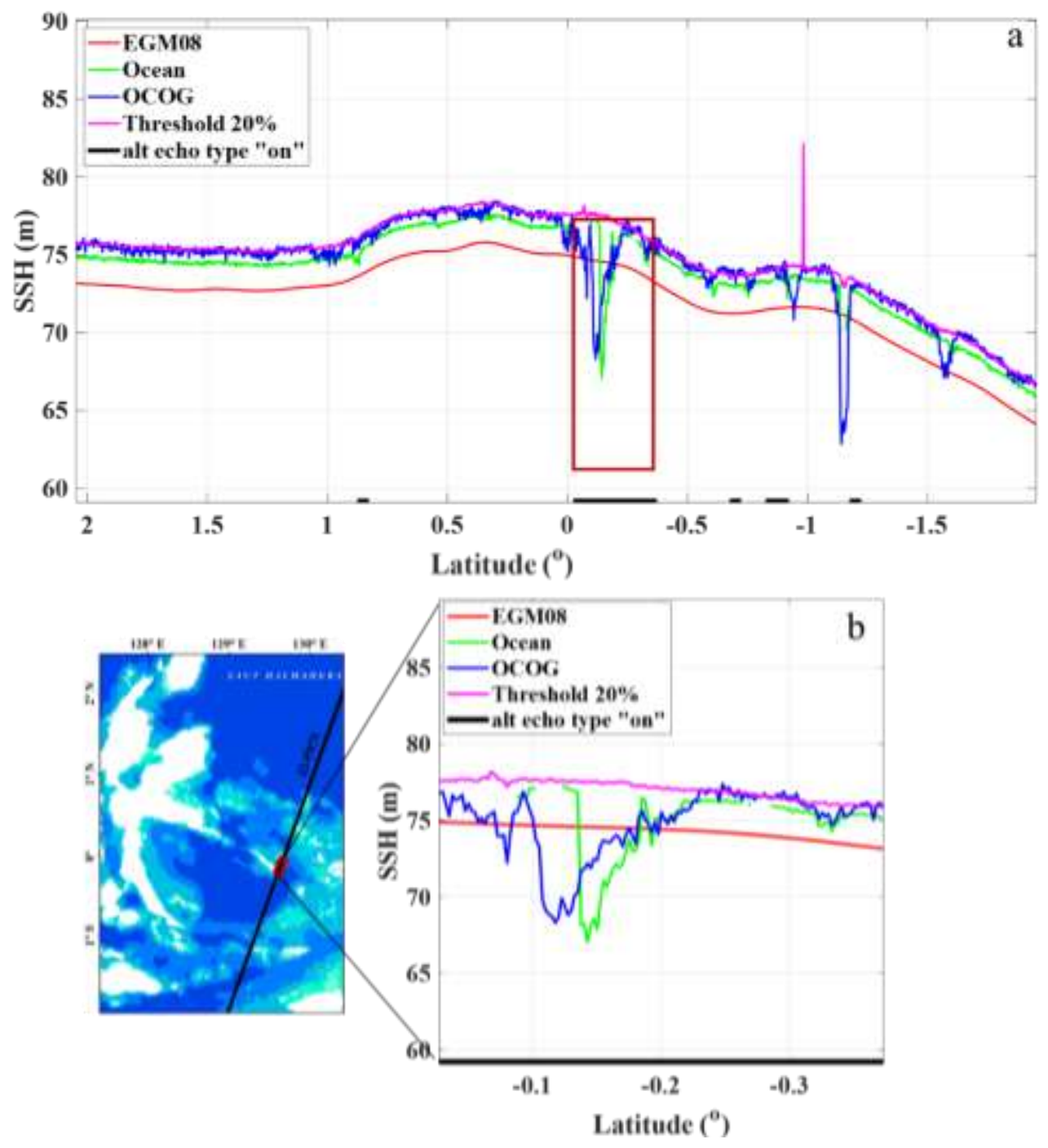

Gambar 6. SSH hasil retracking waveform satelit Jason-2 pass 075 di Laut Halmahera. (a) full track, (b) bagian alt echo type "on".

Gambar 6b memperlihatkan noise ditandai dengan pola garis $\mathrm{SSH}$ hasil estimasi SSH hasil perhitungan on-board retracking berada di atas pola garis $\mathrm{SSH}$ yang sangat jelas ditandai dengan pola garis lembah yang sangat tajam (hijau) bahkan melewati geoid. Kesalahan pengukuran data $\mathrm{SSH}$ tersebut terlihat dapat diperbaiki dengan retracker Threshold 20\% namun tidak untuk OCOG. OCOG tidak mem-berikan akurasi yang lebih baik dan hasil SSH-nya tidak mengikuti pola geoid, namun metode ini setidaknya mampu memberikan estimasi SSH pada bagian yang tidak memiliki data $\mathrm{SSH}$ ocean. Secara umum, SSH hasil retracker yang diaplikasikan ke data altimeter ini menghasilkan ketinggian yang over estimated ocean.

Persentase perbaikan estimasi data SSH Jason-3 pass 164 menunjukkan performa yang berbeda pada bagian atas Pulau Gag dengan bagian bawah Pulau Gag (Tabel 3). Tabel 3 memperlihatkan bahwa retracking waveform pada bagian atas Pulau Gag hanya mampu memperbaiki data $\mathrm{SSH}$ hingga $22,48 \%$ sedangkan pada bagian bawah Pulau Gag mencapai 66,9\%. Selain itu, persentase SR juga mem-perlihatkan bahwa Ocean retracker sudah mampu mengestimasi 99,91\% dari total waveform pada bagian atas 
Pulau Gag sehingga terdapat lebih sedikit data yang kosong dibandingkan bagian bawah Pulau Gag. Hal tersebut menunjukkan bahwa tingkat perbaikan data SSH dengan retracking waveform lebih tinggi di perairan yang lebih dangkal dan terdapat banyak pulau-pulau kecil dibandingkan dengan laut dalam. Hasil retracking waveform Jason-2 pass 251 yang melewati pulau-pulau kecil di Great Barrier Reef Australia oleh Idris and Deng (2012) juga menghasilkan IMP yang tinggi yaitu $80,23 \%$. IMP tersebut lebih tinggi bila dibandingkan dengan IMP pada Jason-2 lintasan 099 yang tidak melewati pulau-pulau kecil.

Hasil retracking waveform menunjukkan bahwa terdapat perbedaan retracker terbaik pada Jason-3 pass 164 dan Jason-2 pass 075. IMP tertinggi pada Jason-3 pass 164 di perairan bagian atas pulau Gag yaitu Improved Threshold 20\% sedangkan pada perairan bagian bawah pulau Gag yaitu Threshold 20\%. Adapun retracker terbaik di sepanjang lintasan Jason-2 pass yaitu Threshold 10\%. Sebaliknya, retracker yang memiliki IMP terendah yaitu OCOG yang memiliki nilai IMP negatif baik pada lintasan Jason-3 pass 164 maupun Jason-2 pass 075. Selain itu, Improved Threshold 50\% juga tidak mampu memperbaiki data SSH pada Jason-3 pass 164 bagian atas Pulau Gag dan Jason-2 pass 075.

Performa dari delapan retracker yang diaplikasikan di perairan dekat pulau-pulau kecil baik perairan dalam maupun perairan dangkal tidak memberikan perbaikan yang sama. Namun, terdapat empat retracker yang konsisten mem-berikan perbaikan yang baik untuk perairan dekat pulau-pulau kecil. Retracker tersebut yaitu Threshold $10 \%$, Threshold 20\%, Improved Threshold $10 \%$, dan Improved Threshold $20 \%$. Persentase perbaikan rata-rata perairan dekat pulau-pulau kecil yaitu 35,62\% dengan persentase ratarata Non-Brown waveform sebesar 9,57\%. Adapun retracker yang paling sesuai diaplikasikan pada perairan dekat pulau-pulau kecil yaitu Threshold 20\% untuk Jason-2 dan Threshold $10 \%$ untuk Jason-3.

Tabel 3. Performa hasil retracking waveform Jason-3 pass 164 dan Jason-2 pass 075 dengan beberapa algoritma (retracker) di perairan pulau-pulau kecil dan laut dalam.

\begin{tabular}{|c|c|c|c|c|c|}
\hline \multirow{2}{*}{ Satelit } & \multirow{2}{*}{ Pass } & \multirow{2}{*}{ Region } & \multirow{2}{*}{ Retracker } & \multicolumn{2}{|c|}{ Peforma } \\
\hline & & & & $\operatorname{IMP}(\%)$ & $\mathrm{SR}(\%)$ \\
\hline \multirow[t]{16}{*}{ Jason-3 } & 164 & Lintasan bagian & OCOG & $-188,91$ & 100 \\
\hline & & atas Pulau Gag & Threshold $10 \%$ & 21,52 & 100 \\
\hline & & & Threshold 20\% & 22,00 & 100 \\
\hline & & & Threshold 50\% & 4,00 & 100 \\
\hline & & & Improved Threshold $10 \%$ & 20,57 & 100 \\
\hline & & & Improved Threshold $20 \%$ & 22,48 & 100 \\
\hline & & & Improved Threshold 50\% & $-3,40$ & 100 \\
\hline & & & Ice & 18,43 & 100 \\
\hline & & & Ocean & - & 99,91 \\
\hline & & Lintasan bagian & OCOG & $-202,96$ & 100 \\
\hline & & bawah Pulau Gag & Threshold $10 \%$ & 62,90 & 100 \\
\hline & & & Threshold 20\% & 66,90 & 100 \\
\hline & & & Threshold 50\% & $-34,37$ & 100 \\
\hline & & & Improved Threshold $10 \%$ & 55,62 & 100 \\
\hline & & & Improved Threshold $20 \%$ & 61,44 & 100 \\
\hline & & & Improved Threshold 50\% & 3,20 & 100 \\
\hline
\end{tabular}




\begin{tabular}{|c|c|c|c|c|c|}
\hline \multirow{2}{*}{ Satelit } & \multirow{2}{*}{ Pass } & \multirow{2}{*}{ Region } & \multirow{2}{*}{ Retracker } & \multicolumn{2}{|c|}{ Peforma } \\
\hline & & & & IMP $(\%)$ & SR $(\%)$ \\
\hline & & & Ice & 37,77 & 100 \\
\hline & & & Ocean & - & 92,46 \\
\hline \multirow[t]{9}{*}{ Jason-2 } & 75 & Sepanjang Lintasan & OCOG & $-83,63$ & 100 \\
\hline & & di Laut Halmahera & Threshold $10 \%$ & 66,19 & 100 \\
\hline & & & Threshold 20\% & 59,69 & 100 \\
\hline & & & Threshold 50\% & 4,13 & 100 \\
\hline & & & Improved Threshold 10\% & 64,94 & 100 \\
\hline & & & Improved Threshold 20\% & 62,52 & 100 \\
\hline & & & Improved Threshold $50 \%$ & $-2,35$ & 100 \\
\hline & & & Ice & 25,93 & 100 \\
\hline & & & Ocean & - & 97 \\
\hline
\end{tabular}

\section{KESIMPULAN}

Retracking waveform data satelit altimeter di Laut Halmahera dengan Threshold 10\%, Threshold 20\%, Threshold 50\%, Improved Threshold 10\%, Improved threshold 20\%, Improved Threshold 50\%, dan Ice memberikan perbaikan data SSH mulai dari $3.2 \%$ sampai $96.71 \%$ sedangkan retracker OCOG tidak mampu memberikan perbaikan. Tidak ditemukan adanya satu retracker yang terbaik di Laut Halmahera baik di perairan teluk maupun perairan pulaupulau kecil dan laut dalam. Retracker yang paling banyak muncul sebagai retracker terbaik pada satelit Jason-2 dan Jason-3 di Laut Halmahera adalah Threshold 10\%. Nilai IMP tertinggi pada penelitian ini sebesar $96,71 \%$ diperoleh dengan menggunakan algoritma Improved Threshold 10\% pada Jason-2 pass 164 yang melewati Teluk Kao.

Retracking waveform pada teluk dangkal dan sempit memberikan performa yang lebih baik dibandingkan teluk dalam dan perairan dekat pulau-pulau kecil. Persentase perbaikan rata-rata pada teluk dangkal dan sempit yaitu $84,96 \%$, pada teluk dalam dan lebar yaitu $51,03 \%$, dan pada perairan dalam dekat pulau-pulau kecil yaitu 35,62\%. Namun, Non-Brown wave-form lebih banyak ditemukan di perairan teluk dangkal dan sempit (rata-rata $=63,49 \%$ ) dibandingkan dengan teluk dalam dan lebar (rata- rata $=11,51 \%)$ dan perairan pulau-pulau kecil (rata-rata $=9,57 \%)$. Retracker yang paling baik diaplikasikan pada teluk yang lebih dangkal dan sempit di Laut Halmahera yaitu Threshold 10\% sedangkan pada teluk dalam dan lebar yaitu Threshold 50\%. Adapun retracker yang cocok diaplikasikan pada perairan dekat pulau-pulau kecil di Laut Halmahera yaitu Threshold $10 \%$ dan Threshold $20 \%$.

\section{UCAPAN TERIMAKASIH}

Penelitian ini dibiayai oleh Direktorat Jenderal Penguatan Riset dan Pengembangan, Kementrian Riset dan Teknologi Pendidikan Tinggi melalui Program Penelitian Pendidikan Magister Menuju Doktor untuk Sarjana Unggul (PMDSU) tahun anggaran 2019 dengan nomor kontrak No. 3/E1/KP.PTNBH/2019 tanggal 29 Maret 2019 dan Surat Perjanjian Penugasan Pelaksanaan Penelitian PMDSU dengan nomor kontrak No. 4252/IT3.L1/ PN/2019 tanggal 4 April 2019 (PI: Dr. Ir. Bisman Nababan, M.Sc.). Penulis mengucapkan terima kasih AVISO dan European Space Agency yang telah menyediakan data satelit altimetri untuk penelitian ini. Penulis juga mengucapkan terima kasih kepada anonymous reviewers yang telah memberikan masukan dan komentar yang konstruktif untuk me-ningkatkan mutu paper ini. 


\section{DAFTAR PUSTAKA}

Adrian D. 2013. Waveform retracking Satelit Jason-2 pada pesisir selatan Jawa Tengah dan Jawa Barat. Skripsi. Departemen Ilmu dan Teknologi Kelautan. Institut Pertanian Bogor. 49 hlm.

Andersen O.B. and R. Scharroo. 2011. Range and geophysical corrections in coastal regions: and implications for mean sea surface determination. In: Vignudelli S., A. Kostianoy, P. Cipollini, J. Benveniste, (ed.). Coastal Altimetry. Berlin (DE): Springer. 103-145 pp.

Anzenhofer M., C.K. Shum, and M. Rentsh. 1999. Coastal altimetry and applications. Columbus (US): The Ohio State University. 36 p.

Bao L., Y. Lu, and Y. Wang. 2008. Improved retracking algorithm for oceanic altimeter waveforms. Progress in Natural Science, 19: 195-203. https://doi.org/10.1016/j.pnsc.2008.06 .017

Brown G.S. 1977. The average impulse response of a rough surface and its applications. IEEE Trans. Antennas Propag., 25: 67-74. https://doi.org/10.1109/TAP.1977.114 1536

Chelton D.B., J.C. Ries, B.J. Haines, L. Fu, and P. Callahan. 2001. Satellite altimetry. In: Fu L. and A. Cazenave (ed.). Satellite Altimetry and earth sciences: A Handbook of Techniques and Applications. San Diego (US): Academic Press. 1-132 pp.

Davis C.H. 1995. Growth of the Greenland ice sheet: a performance assessment of altimeter retracking algorithms. IEEE Trans. Geosci. 33(5): 11081116. https://doi.org/10.1109/36.469474

Davis C.H. 1997. A robust threshold retracking algorithm for extracting ice-sheet surface elevation from satellite radar altimeters. IEEE Trans. Geosci., 35(4): 974-979. https://doi.org/10.1109/IGARSS.1996 .516800

Deng X. and W.E. Featherstone. 2006. A coastal retracking system for satellite radar altimeter waveforms: application to ERS-2 around Australia. J. of Geophysical Research, 111: 1-16. https://doi.org/10.1029/2005JC003039 Gommenginger C., P. Thibaut, L. FenoglioMarc, G. Quartly, X. Deng, J. GomezEnri, P. Challenor, and Y.G. Gao. 2011. Retracking altimeter waveforms near the coasts. In: Vignudelli S., A. Kostianoy, P. Cipollini and J. Benveniste . Coastal altimetry. Berlin (DE): Springer. 61-101 pp.

Guo J.Y., Y.G. Gao, C. Hwang, and J.L. Sun. 2010. A multi-subwaveform parametric retracker of the radar satellite altimetric waveform and recovery of gravity anomalies over coastal oceans. Sci. China Earth Sci., 53(4): 610- 616.

https://doi.org/10.1007/s11430-0090171-3

Hakim M.R., B. Nababan, dan J.P. Panjaitan. 2015. Peningkatan akurasi estimasi tinggi paras laut melalui analisis retracking waveform satelit jason-2 di laut jawa. J. Ilmu dan Teknologi Kelautan Tropis, 7(2): 771-790. https://doi.org/10.29244/jitkt.v7i2.112 54

Hwang C., J.Y. Guo, X. Deng, H.Y. Hsu, and Y.T. Liu. 2006. Coastal gravity anomalies from retracked Geosat/GM altimetry: improvement, limitation and the role of airbone gravity data. $J$. Geod, 80: 204-216. https://doi.org/10.1007/s00190-0060052-X

Idris N.H and X. Deng. 2012. The retracking technique on multi-peak and quasispecular waveforms for Jason-1 and Jason-2 missions near the coast. 35(S1): 217-237. 
https://doi.org/10.1080/01490419.201 2.718679

Idris N.H., X. Deng, A.M.M. Din, and N.W. Idris. 2017. CAWRES: a waveform retracking fuzzy expert system for optimizing coastal sea levels from Jason-1 and Jason-2 satellite altimetry data. Remote Sensing, 9(603): 1-22. https://doi.org/10.3390/rs9060603

Lee H., C.K. Shum, W. Emery, S. Calmant, S. Deng, C.Y. Kuo, C. Roesler, and Y. Yi. 2010. Validation of Jason-2 altimeter data by waveform retracking over California coastal ocean. Marine Geodesy, 33(S1): 304-316.

https://doi.org/10.1080/01490419.201 0.488982

Lumban-Gaol, J., D. Adrian, S. Vignudelli, R. R. Leben, I.W. Nurjaya, T. Osawa, P. Manurung, P. and R.E. Arhatin. 2018. An assessment of a coastal altimetry data product in the Indonesian Waters. IOP Conf. Ser.: Earth and Environ., 176: 012034. https://doi.org/10.1088/17551315/176/1/012034

Martin T.V., H.J. Zwally, A.C. Brenner, and A. Bindschadler. Analysis and retracking of continental ice sheet radar altimeter waveforms. J. Geophy. Res. 88(C3): 1608-1616. https://doi.org/10.1029/JC088iC03p01 608

Nababan, B., M.R. Hakim, and J.P. Panjaitan. 2018. Waveform Identification and Retracking Analyses of Jason-2 Altimeter Satellite Data for Improving Sea Surface Height Estimation in Southern Java Waters and Java Sea, Indonesia. IOP Conf. Ser.: Earth and Environ. Sci., 149: 012057. https://doi.org/10.1088/17551315/149/1/012057

Nababan B., R. Hakim, D. Adrian, dan J. Lumban-Gaol. 2014. Identifikasi waveform data satelit altimeter pada perairan pesisir dan laut dalam di perairan selatan Jawa. J. Ilmu dan
Teknologi Kelautan Tropis, 6(2): 445459.

https://doi.org/10.29244/jitkt.v6i2.902 1

Pamungkas M. 2014. Waveform retracking satelit Jason 2 tahun 2012 di pesisir Pulau Mentawai, Sumatera Barat. Skripsi. Departemen Ilmu dan Teknologi Kelautan. Institut Pertanian Bogor. 48hlm.

Passaro M., P. Cipollini, S. Vignudelli, G.D. Qurtly, and H.M. Snaith. 2014. ALES: A multi-mission adaptive subwaveform retracker for coastal and open ocean altimetry. Remote Sens. Environ., 145: 173-189. https://doi.org/10.1016/j.rse.2014.02. 008

Roscher R., B. Uebbing, and J. Kusche. 2017. STAR: Spatio-temporal altimeter waveform retracking using sparse representation and conditional random fields. Remote Sens. Environ., 201: 148-164.

https://doi.org/10.1016/j.rse.2017.07. 024

Sanwell D.T. and W.H.F. Smith. 2005. Retracking ERS-1 altimeter waveforms for optimal gravity field recovery. Geophys. J. Int., 163: 7989.

Saraceno M., C.G. Simionato, and L.A. RuizEtcheverry. 2014. Sea surface height trend and variability at seasonal and interannual time scales in the Southern South American continental shelf between $27^{\circ} \mathrm{S}$ and $40^{\circ} \mathrm{S}$. Cont. Shelf Res., 91: 82-94. https://doi.org/10.1016/j.csr.2014.09.0 02

Sumerta K.S. 2013. Waveform retracking satelit Jason 2 di Perairan Jawa Timur. Skripsi. Departemen Ilmu dan Teknologi Kelautan. Institut Pertanian Bogor. $104 \mathrm{hlm}$.

Wang X., K. Ichikawa. 2017. Coastal waveform retracking for Jason-2 Altimeter Data Based on Along-Track 
Echograms around the Tsushima Island in Japan. Remote Sensing, 9(762): 1-13.

https://doi.org/10.3390/rs9070762

Wingham D.J., C.G. Rapley, and H. Griffiths. 1986. New technique in satellite altimeter tracking systems. IGARSS'86 Symposium Diges., 1: Received : 23 August 2019 185-190.

Reviewed : 10 September 2019

Yang Y., C. Hwang, H.J. Hsu, E. Dongchen, Accepted :05 Desember 2019

\footnotetext{
and H. Wang. 2012. A subwaveform
}

threshold retracker for ERS-1 altimetry: a case study in the Antartic Ocean. Computers \& Geosciences., 41: 88-98.

https://doi.org/10.1016/j.cageo.2011.0 8.017 
